\title{
Students discipline problems perception of counseling services: a qualitative analysis
}

\author{
Abu Yazid Bin Abu Bakar ${ }^{1}$, Cynthia Shamini Dawson ${ }^{1}$, Ifdil Ifdi1 ${ }^{\left.2^{*}\right)}$ \\ ${ }^{1}$ Universiti Kebangsaan Malaysia, Malaysia \\ ${ }^{2}$ Universitas Negeri Padang, Indonesia
}

\begin{tabular}{l}
\hline Article Info \\
\hline Article history: \\
Received Sep $09^{\text {th }}, 2020$ \\
Revised Oct $19^{\text {th }}, 2020$ \\
Accepted Nov $07^{\text {th }}, 2020$ \\
\hline
\end{tabular}

\section{Keyword:}

Counseling,

Discipline,

High school,

Student perception,

\begin{abstract}
This study aims to discuss the perceptions of high school students towards guidance and counseling services. The aim of this study is to identify students' perceptions of counseling sessions and to identify the services that students prefer. The sample of this study is 4 students comprising form four and five who attend national school from a famous Tuition Center in Butterworth, Penang. This study used interview sessions to collect data. The interview protocol comprises 10 unstructured questions that include the student's background, situation at home, the reasons they do not see the counselor and the student's choice of services other than counseling. We conducted theme analysis based on the respondents' feedback. The results showed that students had a negative perception regarding meetings with counselors.
\end{abstract}

(C) 2020 The Authors. Published by Redwhitepress.

This is an open access article under the CC BY-NC-SA license (https://creativecommons.org/licenses/by-nc-sa/4.0/

\section{Corresponding Author:}

Ifdil Ifdil

Universitas Negeri Padang

Email: ifdil@konselor.org

\section{Introduction}

Counseling is the relationship between a caring person and a person who needs it (Bett, 2013; Getachew, 2020). The British Association for Counseling and Psychotherapy (BACP) states that "Formal Counseling is performed by a professional counselor who acts in a particular role and follows a recognized code of ethics that requires confidentiality, accountability, supervision and ongoing professional development" (Falzon, Frendo, \& Muscat, 2019; Felicia, 2018). WHO report many mental conflicts have influenced students to commit suicide, genocide, alcoholism, drug abuse and for depression, stress, anxiety and psychosomatic illness can be seen to increase among students compared to the situation past (Mugwang'a \& Achieng, 2019; Odebode, 2020).

The field of Counseling Services is when a counselor holds a session with a student (Anuar, Mahmud, \& Karim, 2019; Brown, 2020). Among the forms of services provided are individual counseling sessions that are sessions that involve only counselors and students only. The purpose is to discuss student problems and help students solve problems. Individual counseling is more about personal matters and confidentiality. Apart from that, sometimes there are students who come to meet the counselor just to get guidance want to know how to learn. Here, the counselor needs to conduct a guidance session is to give guidance to students (Branco \& Bayne, 2020; Cunanan \& Maddy-Bernstein, 1994).Students assume the role of counselor is to be a coordinator or leader and mention that misunderstandings of the role of school counselors still exist (Aydin \& Odaci, 2020; Kuhn, 2004). 
Confidentiality is a very important factor in counseling between clients and counselors (Doshi, Robak, Grffin, \& Ward, 2020; Mustaffa \& Ahmad, 2005). Factors concerned with confidentiality have prevented students in this research from seeing counselors to solve their problems. This is cause that the students are worried that the weaknesses and problems told to the counselor will affect and come back to them. Among them worried that counselors will contact their parents and teachers. They also think counselors will misunderstand them and will direct them to do something they dislike (Šarić, Jeznik, Maž gon, \& Mrvar, 2020).

Students felt anxious after telling the counselor the problems they were facing (Lynch, 1999; Yarram, 2020). Students could not predict what would happen after the exposure (Salleh, Yusof, \& Ishak, 2010). The results also prove that anxiety factors are global factors that students go through that do not depend on geographical and cultural factors and the findings of a student evaluation study on Guidance and counseling in the United States (Hanin Hamjah, Mohd Arifin, Ismail, \& Mastor, 2020; Wiggins \& Moody, 1987) . They found the students happy with the appointment arranged with the counselor. The results also show that the cultural factors of society influence students' perceptions of the role of appointments. The people in the west are more open in terms of appointments compared to the Malaysian society (Abdullah, et al., 2020; Alatas, 2020). We should assure students that they will be safe even after we know their problems. We should reassure students they do not have to worry about any negative effects after seeing a counselor. We can achieve this if students and counselors have a good relationship, so they feel there is no gap for them to express their feelings and problems (Bakar, Mejah, \& Amat, 2020).

The role of counselors and counseling in society is still low, because we consider counseling too personal (Chen \& Kok, 2017; Mansor, Sanasi, Nor, Nasir, \& Wahab, 2017). Worse, some argue that if a student or individual meets with their counselor, they are ill (Bakar \& Zakaria, 2018; Low, Kok, \& Lee, 2013). This is a misconception, and we should remove this perception. In addition, the understanding of Malaysian society in the past to the present and we see the actual role and function of counselors and counseling services in bringing about change to them as limited. Students and the community are still hesitant and ashamed to meet a counselor (Ahmad \& Salim, 2011; Kok \& Low, 2017). As students are a natural asset of the country which will play an important role in shaping the economy, politics and society in our country, research efforts should be made to study students' perceptions and needs of counseling so that such help can help them enhance comprehensive development in terms of spiritual, intellectual and emotional (Zakaria, Reupert, \& Sharma, 2013).

Although studies on students are conducted, we conducted this study to examine their perceptions of counseling services so they benefit from such help. There is still a lot of fear and anxiety from students at school to meet or make an appointment with a counselor (Ibrahim, 2002; Jamar, Mansor, \& Noh). Thus, the aim of this study is to (a) determine the reasons students do not meet with school counselors and (b) identify the student services that prefer school counseling services.

\section{Method}

\section{Research design}

We have used qualitative research design. Qualitative research design is a design that uses oral descriptions of behaviors and experiences generated from the process of interpretation and analysis of observations (Cook, 2013; Kemparaj \& Chavan, 2013). I chose this research design because it allows me to find in-depth information on the topic being studied.

\section{Participants}

The sample of this paper comprised 4 students, of which two were girls and two were boys. Only high school students select because they are mature enough to make the choice to see a counselor. Non-probability sampling methods using for the sample of participants.

\section{Instrument}

To analyze the research data used content analysis "content analysis", which is a technique to draw conclusions by objectivity that identifies certain characteristics of the message (Luckner, Sebald, Cooney, Young III, \& Muir, 2005). The data record with a cell phone voice recorder and the information categorize and organized. Self-built semantic interview guides used for each individual interview.

\section{Data collection and analysis}

The tuition teacher selected four students with disciplinary problems and abnormal behavior based on their observations and complaints by the subject teacher. Examples of issues are; not completing homework, talking too much in class, playing with a cell phone and arguing with a teacher. I interviewed these students one by 
one in a private room provided by the center. Each interview session takes about 40 minutes per student. The data collection techniques used in this work are semi-structured interviews (Breakwell, 2006). Using a semistructured interview, the interviewer is free to ask questions in what way he or she thinks is appropriate and natural, and in whatever sequence feels most effective in the situation. Researchers are also free to investigate further information (Brynard \& Hanekom, 2006).

\section{Results and Discussions}

Based on the demographic profile of the student client, the semi-structured items contained in this section are age and gender.

Table 1. Student demographic profile

\begin{tabular}{llll}
\hline No & $\begin{array}{l}\text { Student } \\
\text { (Not real name) }\end{array}$ & Age & Gender \\
\hline Student 1 & Chu Mei Ling & 16 & Female \\
Student 2 & Kumaran Ganagopi & 17 & Male \\
Student 3 & Firdaus, Mohd. Imran & 17 & Male \\
Student 4 & Dorothy Lim & 16 & Female \\
\hline
\end{tabular}

The four students are from Butterworth, Penang. The first student is sixteen years old and a girl. The teacher asked him to come for this interview session because he did not complete the work given by his teacher. He is also said to be silent in class. When he entered the room, I as the trainee counselor found that he scared and nervous and also had no eye contact during our conversation. We descend upon him from King Uda, Butterworth, and are the third of four siblings. He went to SMK Dato 'Onn school. This student stated that she had difficulty focusing on schoolwork because her parents were always debating at home. So when this happens, he listens to loud music and watches movies. When asked why he did not see a counselor, he stated that the counselor could not understand what he was going through and that he was afraid that the counselor would mention it to his parents. He goes to his best friend for emotional help.

The next student was a 17-year-old boy and went to SMK St. Mark. He call because he was always talking in class and always looking at his phone. The teacher caught him playing video games twice during the lesson. During the interview he mentioned that the class was boring. He is the youngest of three siblings. He mentioned that his father was hot tempered and always scolded him. Every time that happened, he felt sad and useless. When asked about counseling services at school, he feared counselors would go to parents and teachers to complain about it and did not want any problems in law. Do not want to label as a troubled child at school to save embarrassment in front of his friends. And making an "appointment" with a counseling teacher will be a hard process.

The third student is 17 years old and went to SMK Dato 'Onn school. He sent because he daydreamed in class, ran away from the classroom for a long time and did not submit any homework. I asked if this claim was true, and the student admitted that they were right. When asked why, the student expressed a lack of interest in the subject and the way teachers teach is boring. When asked what he daydreams about, the student thinks about new movies. When asked about counseling problems at school, he mentioned that students who go there have mental illness. For example, crying for no reason in class and higher for more severe cases. The student mentioned a man coming into the hall with a black wound on his face. Later, he sent to a school counselor. Students say that it is not possible for a counselor to understand issues about adolescence, because teachers in schools scold students for no reason.

The fourth student is 16 years old and went to SMK Convent Butterworth. I asked this student to come because he always talked to his friends, had a low grade at school and refused to do his homework. He also argued with the teacher there. When I saw him, I saw his expression was bitter and when talking about his parents, his tone became louder and increased in volume. He also used strong hand gestures. He claims that his father met another woman. When I asked about counseling services at school, at first he refused to answer but after a few seconds of small talk, then he opened up to mention that it was difficult to meet with a counseling teacher because he was always not there. And the counselor will not understand how he feels and can complain to his parents. 


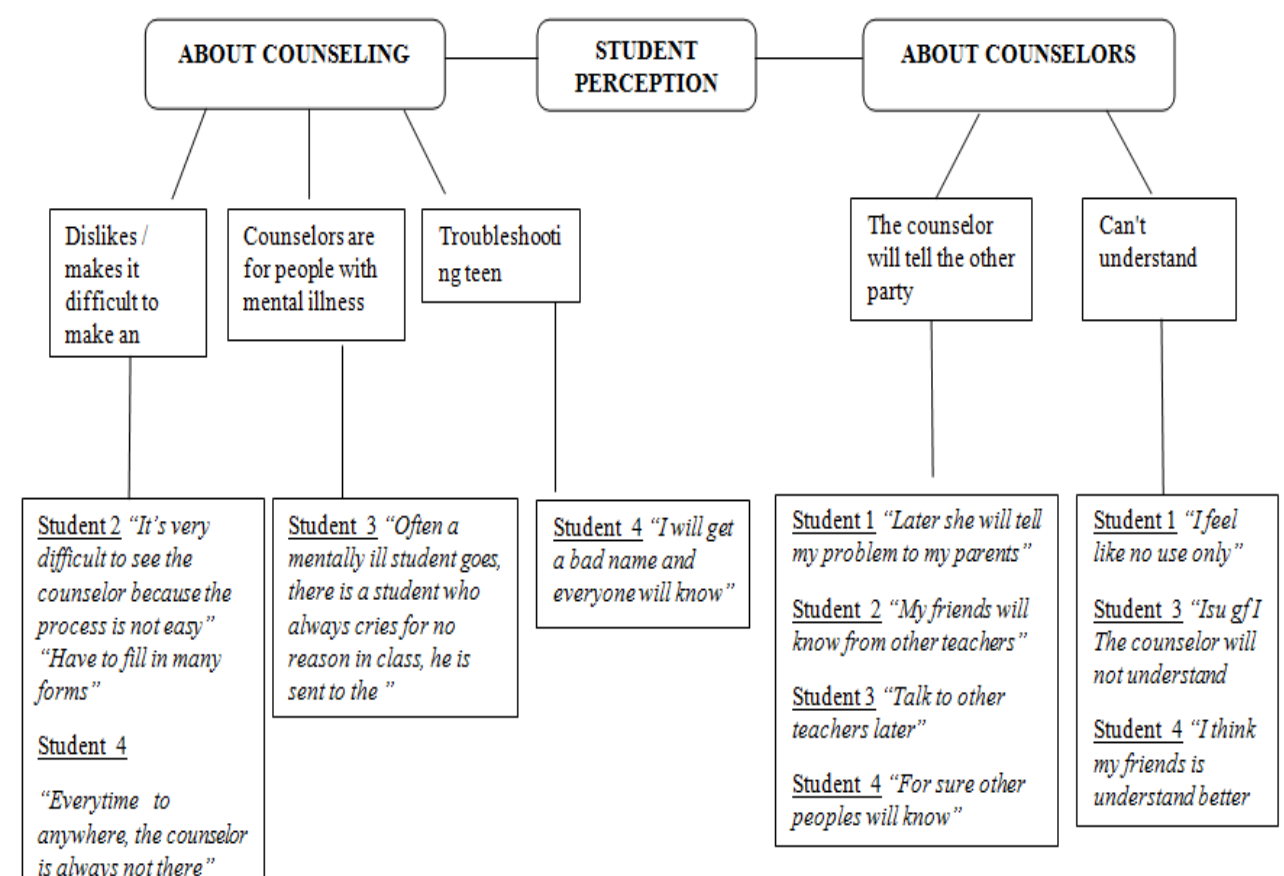

Figure 1. Students' perceptions of the role of guidance and counseling services

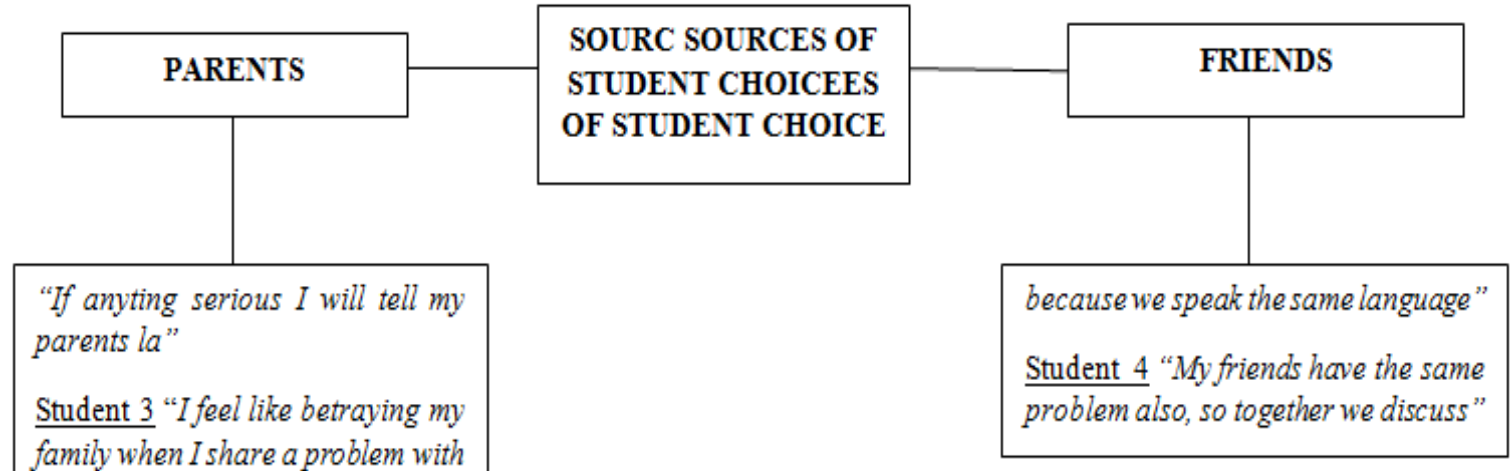

Figure 2. Types of student services that prefer school counseling services

\section{What are students' perceptions about the role of guidance and counseling services?}

The results of the interviews found that although the school students in this study agreed that the counseling session helped them solve the problem but they did not meet with the counselor to solve the problem because they considered their problem not a serious level to meet with the counselor. They also think their problems are not important. Sometimes students think their personal problems are not important so they should see a counselor (Hossain, Min, Muhammad, \& Mani, 2020).

The least reason students do not see a counselor is the fear that the counselor will gossip to other friends and teachers. And also tell their mother. When interviewed, all four students gave the same reason for not wanting to see the counselor. Students fear that their personal issues will spread.

Student 1: "Later she will tell my problem to my parents"

Student 2: "My friends will know from other teachers"

Student 3: "Talk to other teachers later"

Student 4: "For sure other peoples will know"

Other than that, the second highest reason in this interview is that counselors are unable to understand themselves. Students are concerned that counselors will not be able to help them in their daily issues because they are adults and cannot understand their "small" issues. 
Student 3: "I think the counselor will not understand"

Student 1: "I feel like no use only"

Student 4: "I think my friends is understand better"

The results of the interviews also show that the students in this study do not agree with the way of appointment (appointment) to meet with the counselor because when the time to meet with the counselor, the feeling to tell the problem decreases "diminishes". They feel more comfortable if the meeting is held anytime that is when they are facing the problem. They feel 'naughty' to make an appointment and the problem will be postponed and resolved delayed. They feel that meeting their peers is easier because the problem will be solved quickly.

\section{To identify the type of student service that prefers school counseling services?}

Subsequent analysis also found that most students trusted their peers more because they considered counselors to be more mature than them and difficult to understand the feelings of teenagers like them. Thus, for students, peers are people they trust more than counselors to solve their problems. Students also trust their parents and feel like they are betraying their family if they go to others for help.

Pelajar 1: "My friends is better because we speak same language"

Pelajar 4: "My friends have the same problem also, so together we discuss"

Pelajar 3: "I feel like betraying a family when sharing a problem with another adult"

\section{Conclusions}

Counselors play a very important role in enhancing students' potential and helping with the difficulties they face. Students in this study believe that counseling services in schools can help them and in other problems. Therefore, efforts from the government need to stepped up to raise awareness among students on the role of counseling in schools. For example, disseminating information through advertisements, talks and in public places. In addition, the government should hold courses or seminars for counselor teachers to provide exposure and improve the ability of counselors in carrying out counseling duties in schools. In addition, schools should hold Counseling Week to increase students 'awareness of the benefits of counseling and to change students' perceptions of the role of counselor teachers. Therefore, a counselor should also be informal with students by always saying hello and always open a counseling room so that students can feel comfortable to share their problems. having counselors of different genders is ideal to make students more comfortable when sharing problems. The results-study reveal that school students still do not understand the role of counseling services in schools. Awareness should be given to students from various parties so they can learn more about counseling services and be able to have a healthier mind that can reduce negative social problems in the region and also in Malaysia.

\section{References}

Abdullah, Z., Abdul Aziz, S. H., Sodri, N. A., Mohd Hanafiah, A. N., Ibrahim, N. I., \& Johari, M. Z. (2020). Issues and Challenges in Implementing Care Coordinator in Primary Healthcare in Malaysia: A Qualitative Study. Journal of Primary Care \& Community Health, 11, 2150132720956478.

Ahmad, A., \& Salim, S. (2011). The effect of psychological intervention in reducing disciplinary cases among malaysian secondary school students. Procedia Social and Behavioural Sciences, 30, 2592-2596.

Alatas, S. M. (2020). Applying Syed Hussein Alatas's Ideas in Contemporary Malaysian Society. Asian Journal of Social Science, 48(3-4), 319-338.

Anuar, N. H., Mahmud, Z., \& Karim, D. N. F. M. (2019). Informal caregiving of senior parents in Malaysia: Issues \&amp; counselling needs. [Article]. International Journal of Innovation, Creativity and Change, 5(6), 408-420.

Aydin, F., \& Odaci, H. (2020). School Counsellors' Job Satisfaction: What is the Role of Counselling SelfEfficacy, Trait Anxiety and Cognitive Flexibility? Journal of psychologists and counsellors in schools, 114.

Bakar, A. Y. A., Mejah, H., \& Amat, S. (2020). Qualitative expert views' on the feasibility of tele-counseling services in Malaysia. [Article]. Journal of Education and e-Learning Research, 7(3), 270-276.

Bakar, A. Y. A., \& Zakaria, Z. (2018). Counselling services for gifted students in Malaysia: A qualitative exploration. [Article]. International Journal of Engineering and Technology(UAE), 7(2), 66-69.

Bett, J. C. (2013). The importance of promoting the value and the role of peer counseling among students in secondary schools. International Journal of Economy, Management and Social Sciences, 2(6), 477-484. 
Branco, S. F., \& Bayne, H. B. (2020). Carrying the burden: Counselors of color's experiences of microaggressions in counseling. Journal of Counseling \& Development, 98(3), 272-282.

Breakwell, G. M. (2006). Interviewing methods. Research methods in psychology, 3, 232-253.

Brown, C. H. (2020). School Counselors' Response to School Shootings: Framework of Recommendations. Journal of Educational Research and Practice, 10(1), 18.

Brynard, P., \& Hanekom, S. (2006). Introduction to research in management-related fields: Van Schaik.

Chen, K. S., \& Kok, J. K. (2017). Barriers to seeking school counselling: Malaysian Chinese school students' perspectives. Journal of psychologists and counsellors in schools, 27(2), 222-238.

Cook, M. (2013). South Africa's mother tongue education challenge. Paper presented at the Curriculum and Transformation Conference, held at Pretoria, University of South Africa, on.

Cunanan, E. S., \& Maddy-Bernstein, C. (1994). The Role of the School Counselor. Office of Special Populations' BRIEF, 6(1), n1.

Doshi, P. V., Robak, R. W., Grffin, P. W., \& Ward, A. W. (2020). Confidentiality in Counselor Experiential Training Groups: An Exploratory Study. Journal of Counseling Research and Practice, 5(1), 3.

Falzon, R., Frendo, C., \& Muscat, M. (2019). Paving the Way for Counselling? The Link between Maltese PSD Model and Counselling. Journal of School-Based Counseling Policy and Evaluation, 1(2), 3.

Felicia, O., Yusif, D. B., Agyeman, N. P., \& Kwasi, O. A. . (2018). Assessment of Guidance Services in Senior High Schools in Upper Denkyira East Municipality. . British Journal of Education, 6(5), 68-83.

Getachew, A. (2020). Assessment of Guidance and Counselling Service Centre in Higher Education Institutions: A Qualitative Research. Int J Sch Cogn Psychol, 7, 223.

Hanin Hamjah, S., Mohd Arifin, S., Ismail, Z., \& Mastor, K. (2020). Islamic Spiritual Approach in Developing a Positive Mindset. International Journal of Innovation, Creativity and Change., 10(10), 644654.

Hossain, M. M., Min, R. B. M., Muhammad, Z., \& Mani, K. K. C. (2020). Effectiveness of mobile SMS based counselling intervention in improving the knowledge, attitude, and practices of HIV/AIDS patients enrolled in hospitals/NGOs in Terengganu, Malaysia: A mixed mode study protocol. [Article]. BMC Public Health, 20(1).

Ibrahim, R. (2002). Analisa Keperluan Kaunseling Kerohanian Dalam Mambina Tingkahlaku Pelajar Menghormati Guru Kajian Di Sekolah Menengah Kebangsaan Agama Negeri Johor. Universiti Teknologi Malaysia.

Jamar, A., Mansor, F. N., \& Noh, M. A. C. Kefahaman Dan Pengamalan Nilai Islam Dalam Kalangan Pelajar "Ground Handling" Di Kolej Swasta Malaysian Aviation Training Academy (MATA) Kuantan.

Kemparaj, U., \& Chavan, S. (2013). Qualitative research: a brief description. Indian Journal of Medical Sciences, 67.

Kok, J. K., \& Low, S. K. (2017). Proposing a collaborative approach for school counseling. International Journal of School \& Educational Psychology, 5(4), 281-289.

Kuhn, L. A. (2004). Student perceptions of school counselor roles and functions.

Low, S. K., Kok, J. K., \& Lee, M. N. (2013). A holistic approach to school-based counselling and guidance services in Malaysia. School Psychology International, 34(2), 190-201.

Luckner, J. L., Sebald, A. M., Cooney, J., Young III, J., \& Muir, S. G. (2005). An examination of the evidence-based literacy research in deaf education. American Annals of the Deaf, 150(5), 443-456.

Lynch, G. (1999). Exploring young people's perceptions relevant to counselling: A qualitative study. British Journal of Guidance and Counselling, 27(2), 231-243.

Mansor, A. N., Sanasi, J., Nor, M. Y. M., Nasir, N. M., \& Wahab, J. A. (2017). Teacher perceptions of managing indiscipline amongst at-risk teenage students: A Malaysian study. International Journal of Advanced and Applied Sciences, 4(5), 112-119.

Mugwang'a, C. A., \& Achieng, S. D. L. (2019). Implementation of Guidance and Counseling Programme and Implications on Academic Performance of Students in Muhoroni, Kisumu County, Kenya. Journal of Popular Education in Africa, 3(5).

Mustaffa, M. S., \& Ahmad, R. (2005). Pendekatan Temubual Sebagai Metod Kajian Kes. Suatu Persepsi Di Kalangan Pelajar Perempuan Cemerlang Terhadap Perkhidmatan Bimbingan dan Kaunseling

Paper presented at the 3rd International Qualitative Research Convention 2005.

Odebode, A. A. (2020). Awareness of Historical Development of Counselling and its Relevance among Nigerian Youth: Implications for Professional Counsellors. HONAI, 3(1), 57-66.

Salleh, A., Yusof, R., \& Ishak, N. M. (2010). Self-efficacy and counseling competency. [Article]. International Journal of Knowledge, Culture and Change Management, 10(6), 61-70.

Šarić , M., Jeznik, K., Maž gon, J., \& Mrvar, P. G. (2020). 'I know we've got someone in the school I can trust': students' attitudes towards school counselling services in Slovenian schools. Pedagogika, $2020, \mathrm{t}$. 137, nr. 1, p. 117-137. 
Wiggins, J. D., \& Moody, A. H. (1987). Student evaluations of counseling programs: An added dimension. The School Counselor, 34(5), 353-361.

Yarram, M. (2020). Teachers' Perceptions of a Principled Approach to Instruction and the Perceived Changes to Student Engagement. Wilmington University (Delaware).

Zakaria, N., Reupert, A., \& Sharma, U. (2013). Malaysian primary pre-service teachers' perceptions of students' disruptive behaviour. [Article]. Asia Pacific Education Review, 14(3), 371-380. 